\title{
Does Political Connection Tamper with the Corporate Governance Effect of Media Attention
}

\author{
Zhen Lu and Xuelan Zhang \\ School of Finance, Zhongnan University of Economics and Law, Wuhan, 430073, China
}

\begin{abstract}
Keywords: Political Connection, Media Attention, Earnings Management, Corporation Governance,
\end{abstract} Stakeholder.

\begin{abstract}
It is an undisputable fact that political connection influences the internal corporate governance in transitional economies However, on whether and how political connection affects the external stakeholders' governance, in-depth discussion is still needed. Taking private listed companies in China as examples, this paper investigates the effect of political connection on the corporate governance role of media from the perspective of earnings management and finds that earnings management is impacted by media attention through reputation mechanism but not financial penalties, while political connection weakens the governance effect. In light of the findings, market mechanism should be perfected, the independence of media should be guaranteed, and the government's function should be continually transformed to give full play of media governance.
\end{abstract}

\section{Introduction}

Increasingly, the role of media on corporate governance has aroused extensive concern in the academic community. it is generally acknowledged that media coverage acts as signals which affect the decision-making of target audiences, thus lowers information asymmetries of the financial markets and weakens adverse selection and moral hazard (Dyck \& Zingales, 2004; Dyck et al.,2008; Bushee et al., 2010). However, does media attention always constrain market participants? So far, consensus has not been reached in the empirical studies against the background of China. For examples, Li and Shen(2010), Dai(2011), Quan and Wu(2012) argue that media leads a significant role in governing firms' earnings management, furthermore, Kong et al.(2013) emphasize the effect of media coverage on corporate governance in firms' behavior of reducing earnings management; While Yu et al.(2011) insist that media attention is just a management pressure but not an effective supervision, managers manipulate more on earnings management in response to negative media coverage. Does the divergence of the empirical evidences on the effect of media governance originate from some interference facto? This is the first question this paper plans to solve.

Second, in emerging markets especially the developing countries of Southeast Asia prevailing with Confucian culture, political connection spreads throughout the economies and societies with strong deep roots in that firms seek priority for the access to financing (Chiu \& Joh, 2004; Cull \& Xu, 2005), government contracts (Goldman et al., 2009), bailouts (Faccio et al., 2006) and legal protection (Faccio, 2010), which lay negative effects on the economic and financial orders, the micro behaviors, and even the freedom of media coverage, news on wild action of listed firms is reported from time to time. Thus, in the consummating capital market in China, does political connection impact the effect of media coverage on corporate finance? If the answer is "yes" , does political connection hamper or facilitate the role of media coverage? Moreover, which path does it follow? Regretfully, to our knowledge, no answer can be found in related literature. In light of this, from the perspective of earnings management, a kind of ubiquitous behaviors of the listed firms (Lei and Liu, 2006), the paper separates the media coverage into positive reports and negative reports based on a literature review, probes into the effect of political connection on media governance evidenced by Chinese capital markets so as to seek the answers to the above questions and a way to effectively enhance the stakeholders' governance on the behaviors of the listed companies in China.

The paper is expected to make contributions in two ways: firstly, it is found that media attention exerts influence on the firms through the reputation mechanism but not the punishment mechanism 
based on the empirical tests of media governance and a segmentation of media reports; secondly, it is disputable that political connection can act as a substitution of informal institution and affects firms' corporate governance and financial decision in the countries or regions with immature market economies, whereas, no evidence available for the corporate governance effect of external stakeholders such as media is impacted by the political connection. This paper shows evidence of the hampering role of political connection on the media governance sampling with the listed firms in China, namely, the existence of the widely abuse of political power in emerging markets, thus enriches our knowledge on stakeholder governance to a certain extent.

\section{Literature Review}

\section{The Effect of Media Attention on Earnings Management.}

Theoretically, Dyck et al.(2008) argue that the media not only spreads information but also plays a role in corporate governance by increasing the cost of firms' earnings management. Their point of view gains empirical supports: Li and Shen(2010), Dai et al.(2011), Que and Wu(2012), Kong et al.(2013) find that media attention functions significantly in corporate governance, while Yu et al.(2011) suggest that more managerial pressure originated from media coverage lead to higher degree of earnings management; Dyck and Zingales(2004) argue that media attention might decrease the private benefit of the control rights. Miller(2006) reports that media attention is helpful to reveal firms' irregularities and Dyck et al.(2008) suggest that media coverage can increase the probability of the rectification of firms' violation based on an empirical study of Russia in 1999-2002. Moreover, Bushee et al.(2010) find that related media coverage can decrease information asymmetry, while Liu and McConnell(2013) report their finds that he media can play a role in aligning managers' and shareholders' interests by forcing the management to abandon value-reducing acquisition.

\section{Political Connection and Earnings Management.}

Census has not been reached on the definition of political connection although there are so many alternatives 。 The most widely-accepted definition might be the one given by Faccio(2006): the entrepreneurs are connected with the politicians, at least there is one major shareholder or senior manager who is parliament member, or minister, or governor, otherwise has close relationship with senior government officers (Chaney et al., 2011). It is generally acknowledged that political connection is negatively correlated with the quality of earnings in that: firstly, since political connected firms seek the return for the cost they have paid for the connection, the insiders always conceal, obscure or at least postpone earnings report so as to mislead investors (Leuz et al., 2003); secondly, due to the "administrative umbrella" provided by the politicians, companies with political connection do not have to be punished because of the low quality of their accounting information and then disregard disclosure quality; thirdly, firms with poor performance are keen on seeking political connection(Chaney et al., 2011). However, empirical evidence shows contradictory results. For example, Chaney et al.(2011) suggest that the more connected with the politicians, the lower the quality of the firm's accounting information based on an empirical study of 4954 firms of 19 countries (including developed and developing countries) in 1996-2005. In China, Xie and Liu(2009) report that the earnings quality of the political-connected firms is lower than that of those un-connected firms, and political connection has no effect on earnings quality in the context of low level of external legal protection and internal corporate governance which is evidenced by the sample of private listed companies in 2003-2008; while Liu et al.(2013) find that political connection can reduce the level of earnings management based on an empirical study of the private listed companies in Shenzhen Small and Medium Enterprise Board(2009-2011).

In brief, currently available literature reveals the corporate governance effect of media attention as well as the relationship between political connection and earnings quality, but lacks inspection and verification into the functioning mechanism and path of media governance, let alone talk about the impact of political connection on media governance, which is common in practice. In light of this, we try to analyze the mechanism of how political connection lays effect on media governance by logical 
reasoning and modeling based on Dyck et al.(2008)'s rational decision-making model, and then propose our research hypotheses.

\section{Media Attention, Political Connection and Earnings Management: Research Hypotheses}

Whether or how political connection impact on the governance effect of media attention? Borrowing ideas from Dyck et al.(2008), we try to probe into the logical connections of media attention and earnings management as well as the functioning mechanism of political connection on the governance effect of media coverage.

\section{Media Attention and Earnings Management.}

We separate media reports into positives and negatives, denote $n_{1}$ as the total number of media reports, $n_{2}$ as the total number of negative reports, $n_{3}$ as the positives.

Follow Dyck et al.(2008), violation happens only when the related expected private benefit is more than the expected reputation loss and economic punishment. We define the private benefit of managers as a constant, the same as the Dyck et al. (2008). Thus, whether or not corporate violation occurs mainly depends on the expected cost originated from the violation, including expected reputation loss and economic punishment. And media attention leads a role in corporate governance by influencing expected reputation loss and economic punishment. In details:

\section{A. Reputation Loss Mechanism}

When corporate violation is detected, reputation cost $R C$ occurs. While the size of $R C$ is affected by the degree of media attention, specifically, the more positive the media report, the more the firm's reputation loss ( $R C$ ) from the exposure of corporate violation, which means the constraints on violation is enhanced and the reputation loss mechanism does function. Thus, if the governance effect of media attention mainly functions through reputation loss mechanism, then, increase in positive reports might increase the cost of reputation loss resulted from violation and decrease the violation.

\section{B. Economic Punishment Mechanism}

Pressure from public opinion formed by the media attention may affect the size of the economic punishment $P$ for managerial violation, and then affects the probability of the violation. That is, $P$ is affected by the degree of media attention, in detail, the more negative the media reports and the more negatively the media report, the more economic punishment by the authorities because of the higher pressure from public once the violation is revealed by media. Therefore, if the governance effect of media attention mainly functions through economic punishment mechanism, then, the more the number of negative reports, the higher the pressure from public, and then the more economic punishment on violation, which leads less violation of the company.

In sum, as to through which media attention functions in corporate governance, we have $\mathrm{H} 1$ to be tested:

H1: If media governance mainly functions through reputation loss mechanism, then, the increase of the number of positive reports can increase the cost of reputation loss, thus corporate violation decreases; if media governance mainly functions through economic punishment mechanism, then, the increase of the number of negative reports will enhance the pressure from public which is faced by the authorities, the economic punishment imposed on firm increases, thus corporate violation decreases.

\section{Political Connection and the Effect of Media Governance.}

Then, we introduce political connection $p c$. Two kinds of possibilities exist for the impact of political connection on media governance: firstly, political power originated from political connection is abused, the firm can escape from media governance, thus weaken the function of media governance, and political connection can lower the cost of earnings management; secondly, political power originated from political connection is under control, the senior management of politically connected firms values more on media reports for their consideration on career and reputation, which strengthens the governance of media attention, thus increase the cost of earnings management.

When political connection exists and serves as an "umbrella", political power is abused, the managers do no attach importance to media report, political connection enervates the effect of media 
governance; while when political power is effective constrained, the management values personal political career and pays more attention to media coverage, political connection will strengthen the effect of media governance.

So we have H2: if the political power originated from political connection is abused, political connection enervates the effect of media governance; if the political power originated from political connection is constrained, political connection will strengthen the effect of media governance.

\section{Data Sources and Variable Definitions}

\section{Data Sources.}

We take all the companies listed in both Shaihai Stock Exchange and Shenzhen Stock Exchange between 2009 and 2012 as a original example, and refine the sample with a number of additional criteria: (1) considering the latent earnings management in the IPO process, we eliminate all the IPO samples of the year; (2)since the state-owned and state-holding companies are inherently political-connected, which is not helpful to understand the effect of political connection on media governance, so we delete non-private firms, just focus on private listed companies; (3) eliminating the listed firms of financial services industry, ST(special treated), and firms with missing data. Data on financial statements, corporate governance and political connection comes from CSMAR. We obtain the data of media attention from CCND with manual collection according to the key words and the reported emotion. And then, the data is winsorized at the extreme two percentiles (i.e., values less (greater) than the 1st (99th) percentile are set equal to the value of the 1st (99th) percentile). Finally, we have 2344 samples.

\section{Variable Definitions and Measurement.}

\section{A. Earnings Management ( $E M_{i t}$ )}

We use the most widely accepted and the most mature cross-sectional modified Jones model to calculate $E M_{i t}$. The steps are as follows: firstly, calculate total accrued profit $T A, T A=N I-C F O$, where $N I$ is net income, and CFO is cash flow from operation; secondly, according to the industry classification criteria formulated by the China Securities Regulation Committee(CSRC), we do Ordinary OLS to the model of TA with all the samples per year and per industry respectively. Finally, discretionary accruals ( $D A$ ) can be obtained from the difference between total accrued profits and non-discretionary accruals, we measure the degree of earnings management with the absolute values, $E M=|D A|$.

\section{B. Media Attention $\left(\ln \left(1+n_{1}\right), \ln \left(1+n_{2}\right), \ln \left(1+n_{3}\right)\right.$ )}

As to media attention, according to Li and Shen (2010) and Dai et al. (2011), we collect the information of 8 newspapers from CCND by inputting company names in the database and obtaining related news. Firstly, we calculate the total numbers of the news reported on the sample companies by year, denote it as $n_{1}$. And then, based on the content, we judge the tone of the reports-negative or positive, calculate the number of negative and positive reports by company and by year, denote as $n_{2}$ and $n_{3}$. At last, we treat the numbers logarithmically.

\section{Political Connection( $P C$ )}

In light of Fan et al.(2007), we search and judge the background of each senior managers of the listed firms in the Corporate Governance Database to determine whether a firm is politically connected. If the senior manager ( the Chairman of the Board of Directors or the General Manager) is or was a government officer, or a deputy to the People's Congress, or a CPPCC member, then the firm is politically connected, $p c=1$; otherwise, it is not politically connected, $p c=0$.

\section{Control Variables}

Considering the impact of the structure of corporate governance and the financial position on earnings management, we choose the following variables as the control variables: (1)the proportion of the shares held the three largest shareholders; (2) the size of the Board of Directors ,take the 
logarithm; (3)the proportion of the independent directors; (4) the proportion of the shares held the senior management; (5) whether the chairman of the Board of Directors is a shareholder; (6)return on assets, to measure the profitability of the firm; (7) asset-liability ratio, total liabilities at the year of the year /total assets at the year of the year; (8) market-to-book ratio; (9)main business income growth ratio; (10)the size of the firm, the natural logarithm form of the firm's total assets at the year of the year; (11) product market power, in line with Datta et al.(2013), use main business income as the proxy of the producer price, the cost of main business as the proxy of marginal cost, both with industrially adjusted, and then we use Lerner Index of each listed firms minus average Lerner Index of the industry to calculate the market power of each firms; (12)external audit.

\section{Empirical Tests and Analysis}

\section{Empirical Tests.}

A. Media Attention and Earnings Management

We use dynamic panel model to estimate the effect of total numbers of total, negative and positive reports on firms' earnings management so as to capture the dynamic character of the behavior of earnings management. The equations are listed as follows:

$$
\begin{array}{r}
E M_{i, t}=\beta_{0}+\beta_{1} E M_{i, t-1}+\beta_{2} \operatorname{Ln}\left(1+n_{1}\right)_{i, t}+\sum \beta_{j} \text { ControalVariable }_{j}+\varepsilon_{i, t} \\
E M_{i, t}=\beta_{0}+\beta_{1} E M_{i, t-1}+\beta_{2} \operatorname{Ln}\left(1+n_{2}\right)_{i, t}+\beta_{3} \operatorname{Ln}\left(1+n_{3}\right)_{i, t}+\sum \beta_{j} \text { ControlVariable }_{j}+\varepsilon_{i, t}
\end{array}
$$

Table 1 presents the estimated results of the above equations:

Table 1. Media Attention and the Firm’s Earnings Management

\begin{tabular}{lllll}
\hline & Coef. & Z value & Coef. & Z value \\
\hline$E M_{t-1}$ & $-0.5503737^{* * *}$ & -9.33 & $-0.5510913^{* * *}$ & -9.33 \\
\hline $\operatorname{Ln}\left(1+n_{1}\right)$ & $-0.0107195^{*}$ & -1.73 & $/$ & $/$ \\
\hline $\operatorname{Ln}\left(1+n_{2}\right)$ & $/$ & $/$ & -0.0010786 & -0.15 \\
\hline $\operatorname{Ln}\left(1+n_{3}\right)$ & $/$ & $/$ & $-0.0110609^{*}$ & -1.76 \\
\hline
\end{tabular}

Note: ${ }^{*}{ }^{* *}$, and $* * *$ mean significant at the $10 \%, 5 \%$, and $1 \%$ level, respectively.

From table 1 we can find the estimated results of $\mathrm{H} 1$ :

(1) The total numbers of media reports is negatively correlated to earnings management, which suggests that the more the media reports, the less the earnings management. In other words, media does plays a role in corporate governance and can supervise and constraint firms' behavior.

(2) Media governances firms through reputation mechanism but not economic punishment mechanism. As shown in the empirical results, positive reports are negatively correlated to earnings management while the relationship between negative reports and earnings management is not significant. Therefore, media governance does not mainly function through economic punishment mechanism, otherwise, the more the negative reports, the higher the public opinion pressure and the economic punishment, thus the firm decreases its earnings management; and media governance works through reputation mechanism in that more positive reports lead to more reputation loss cost, correspondingly, the earnings management becomes less.

B. Political Connection and the Effect of Media Governance

We use the similar method to investigate the relationship between political connection and the effect of media governance. To describe the role of political connection, we introduce the cross terms of political connection and media reports. Repeating the above analysis scheme, we consider the effect of total, negative and positive reports respectively, and the estimated equations are listed as follows:

$$
E M_{i, t}=\beta_{0}+\beta_{1} E M_{i, t-1}+\beta_{1}^{\prime} P C+\beta_{2} \operatorname{Ln}\left(1+n_{1}\right)_{i, t}+\beta_{2}{ }^{\prime} P C^{*} \operatorname{Ln}\left(1+n_{1}\right)+\sum \beta_{j} \text { ControlVariable }_{j}+\varepsilon_{i, t}
$$




$$
\begin{aligned}
& E M_{i, t}=\beta_{0}+\beta_{1} E M_{i, t-1}+\beta_{1}{ }^{\prime} P C+\beta_{2} \operatorname{Ln}\left(1+n_{2}\right)_{i, t}+\beta_{2}{ }^{\prime} P C^{*} \operatorname{Ln}\left(1+n_{2}\right)+\beta_{3} \operatorname{Ln}\left(1+n_{3}\right)_{i, t}+\beta_{3}{ }^{\prime} P C^{*} \operatorname{Ln}\left(1+n_{3}\right) \\
& +\sum \beta_{j} \text { ControlVariable }_{j}+\varepsilon_{i, t}
\end{aligned}
$$

Estimated results are shown in Table 2.

Table 2. Political Connection and the Governance Effect of Media Attention

\begin{tabular}{lllll}
\hline & Coef. & Z value & Coef. & Z value \\
\hline$E M_{t-1}$ & $-0.5571964 * * *$ & -9.47 & $-0.5595011^{* * *}$ & -9.51 \\
\hline $\operatorname{Ln}\left(1+n_{1}\right)$ & $-0.0172597^{* *}$ & -2.35 & $/$ & $/$ \\
\hline $\mathrm{PC}^{*} \operatorname{Ln}\left(1+n_{1}\right)$ & $0.0223077^{*}$ & 1.82 & $/$ & $/$ \\
\hline $\operatorname{Ln}\left(1+n_{2}\right)$ & $/$ & $/$ & -0.0059905 & -0.68 \\
\hline $\mathrm{PC}^{*} \operatorname{Ln}\left(1+n_{2}\right)$ & $/$ & $/$ & 0.0088823 & 0.65 \\
\hline $\operatorname{Ln}\left(1+n_{3}\right)$ & $/$ & $/$ & $-0.0188006^{* * *}$ & -2.58 \\
\hline $\mathrm{PC} \operatorname{Ln}^{*}\left(1+n_{3}\right)$ & $/$ & $/$ & $0.0291257^{* *}$ & 2.33 \\
\hline $\mathrm{PC}$ & 0.0014065 & 0.06 & -0.0051086 & -0.21 \\
\hline
\end{tabular}

Note: *, **, and $* * *$ mean significant at the $10 \%, 5 \%$, and $1 \%$ level, respectively.

We can obtain the estimated results of $\mathrm{H} 2$ from table 2:

(1) The total numbers of media reports are negatively correlated with earnings management, which implies that the total numbers of media reports have the function of supervision. Meanwhile, the cross term of political connection and the total numbers of media reports is positively correlated with earnings management, the direction of which is opposite to the coefficient of the total numbers of media reports, which means the political connection weaken the governance effect of media coverage;

(2)Neither the relationship between the number of negative reports and earnings management is significant, nor is the relationship between political connection and negative reports;

(3) The numbers of positive reports are significantly negative with earnings management, which means the positive reports constrain firms' behavior through reputation mechanism. Moreover, political connection is positively correlated with the numbers of positive reports, and the sign of its coefficient is the opposite to that of the numbers of positive reports, which implies political connection tamper with the governance effect of media coverage.

In sum, political connection does tamper with the corporate governance effect of media coverage, where political connection mainly acts as an umbrella in that political power cannot constrain firms' behavior but is abused since the firms do not regard media reports and market opinion because of their political connection.

\section{Analysis and Discussion.}

The empirical results show that:

A. Media governances firms mainly through reputation mechanism, while economic punishment mechanism does not work. The main reasons might be:

(1)firstly, an important reason that firms seek political connection is that they regard political connection as a substitute of formal institution to protect their properties effectively so as to advance firms' development (Cull \& Xu, 2005). Actually, confronted with the uncertainties of government policies and administrative management, private firms try to establish good relationship with the local governments, do their best to win honor for the local governments, avoid to fall foul with government officers due to reputation loss, which make reputation mechanism the main function channel of the governance effect of media attention;

(2)secondly, Chinese capital market lacks of the foundation for economic punishment mechanism to constrain listed firms. It is undisputable that Chinese capital market is still under construction and lays more emphasis on funding, and listed firms frequently misappropriate public funds, ignoring the operation and investment, failing to reward investors. On the other hand, the supervisory authorities 
fail to supervise, manage and punish these behaviors, which result in the insufficient pressure from media coverage, thus cannot constrain firms' behavior by economic punishment;

(3)Thirdly, medias in China, who have close relationships with listed firms and local governments and unable to deeply mine firms' information, usually lack of independence. Additionally, driven by the “GDP championship" , local governments tend to spread only the good news and cover the bad, it is very hard to report negative information. Lacking of independence, media cannot function effectively on information digging, violation uncovering and exposure.

B. Political connection does tamper with the governance effect of media coverage.

This indicates that, for the private firms, under the umbrella of political connection, the management does not concern the effect of media reports, thus the governance effect of media coverage is weakened. The possible explanations might be: (1) Interconnected relationship contracts exist between local governments and firm (He and Zhou, 2011). (2) as Sun et al. (2006) point out, politically connected firms obtain tax benefits, government bailouts and grant-in-aid, thus lower the transparency of accounting information.

\section{Conclusions and Policy Implications}

This paper analyzes the effect of political connection on media governance and the main conclusions include: first, media attention affects corporate governance mainly through reputation mechanism but not economic punishment mechanism; second, political connection acts as an "umbrella" of the political-connected firms, thus tampers with the corporate governance effect of media attention. Therefore, three courses of action should be take to put media governance into full play: (1)perfect the institutions and rules of capital market, let the capital market decides the allocation of resources but not treat it as a funding pool so as to effectively decrease earnings management and increase the cost of earnings management, thus lay a solid foundation for media governance; (2)promote independence, objectiveness and professional standard of the medias, let medias bring the role of supervisor and observer into full play, improve the efficiency of media governance; (3)further clarity the boundary of the governments and the firms, transform the functions of governments, reduce government intervention to reach a diminution of political power originated from political connection, monitor and constrain on the rent-seeking behavior of political connection so as to avoid the abuse of political power.

\section{References}

[1] Bushee, B. J., Core, J. E., Guay, W., \& Hamm, S. J. (2010). The role of the business press as an information intermediary. Journal of Accounting Research, 48(1), 1-19.

[2] Chaney, P. K., Faccio, M., \& Parsley, D. (2011). The quality of accounting information in politically connected firms. Journal of Accounting and Economics, 51(1), 58-76.

[3] Chen, C., Li, Z., \& Su, X. (2005). Rent seeking incentives, political connections and organizational structure: Empirical evidence from listed family firms in China. City University of Hong Kong Working Paper.

[4] Chiu, M. M., \& Joh, S. W. (2004). Loans to D istressed Firms: Political Connections. Related Lending, Business Group A ffiliations, and Bank G overnance. Chinese University of Hong Kong, Working Paper.

[5] Cull, R., \& Xu, L. C. (2005). Institutions, ownership, and finance: the determinants of profit reinvestment among Chinese firms. Journal of Financial Economics, 77(1), 117-146.

[6] Dai, Y., Pan, Y. \& Liu, S.(2011). Media Governance, Government Invention and Corporate Governance: evidence of Chinese listed companies from the perspective of financial restatement, World Economy, 11:121-144. 
[7] Dyck, A., \& Zingales, L. (2004). Private benefits of control: An international comparison. The Journal of Finance, 59(2), 537-600.

[8] Dyck, A., Volchkova, N., \& Zingales, L. (2008). The corporate governance role of the media: Evidence from Russia. The Journal of Finance, 63(3), 1093-1135.

[9] Faccio, M. (2010). Differences between Politically Connected and Nonconnected Firms: A Cross - Country Analysis. Financial Management, 39(3), 905-928.

[10]Faccio, M., Masulis, R. W., \& McConnell, J. (2006). Political connections and corporate bailouts. The Journal of Finance, 61(6), 2597-2635.

[11]Fan, J. P., Wong, T. J., \& Zhang, T. (2007). Politically connected CEOs, corporate governance, and Post-IPO performance of China's newly partially privatized firms. Journal of financial economics, 84(2), 330-357.

[12]Goldman, E., Rocholl, J., \& So, J. (2009). Do politically connected boards affect firm value?. Review of Financial Studies, 22(6), 2331-2360.

[13]He, D. \& Zhou, Z.(2011). Private Enterprises’ Political Connection, Employment and Corporate Value, Journal of Quantitative \& Technical Economics, 9:47-60(in Chinese).

[14]Kong, D., Liu, S. \& Ying, Q.(2013). The Role of Media in the Corporate Actions : Is the Fire? Management World,,7:145-162(in Chinese).

[15]Lei, G. \& Liu, H.(2006). Control of the Largest Shareholder, Funding Size and the Level of Earnings Manipulation, Management World, 1:129-136(in Chinese).

[16]Lei, G., Li, S. \& Wang, X.(2009). Political Connection, Auditors’ Choice and Corporate Value, Management World, 7:145-155(in Chinese).

[17]Leuz, C., Nanda, D., \& Wysocki, P. D. (2003). Earnings management and investor protection: an international comparison. Journal of financial economics, 69(3), 505-527.

[18]Li, P. \& Shen, Y.(2010). The Corporate Governance Role of Media: Empirical Evidence from China, Economic Research, 4: 16-27(in Chinese).

[19]Liu, B., \& McConnell, J. J. (2013). The role of the media in corporate governance: Do the media influence managers' capital allocation decisions?.Journal of Financial Economics, 110(1), 1-17.

[20]Liu, Y., Zhang, D. \& Tang, D.(2013). Marketization Degree, Political Connection and Earnings Management:An Empirical Research Based on SMEs Board Listed Companies in Shenzhen, Economy \& Audit Study, 2:49-58(in Chinese).

[21]Miller, G. S. (2006). The press as a watchdog for accounting fraud. Journal of Accounting Research, 44(5), 1001-1033.

[22]Que, X. \& Wu, S.(2012). Study on Governance Effect and Mechanism of Media Attention, Finance \& Trade Economy, 5: 59-67(in Chinese).

[23]Sun, Z., Li, Z. \& Wang, J.(2006). Ownership Structure, Accounting Information and Debt Contracts: Empirical Evidence from the Listed Companies in China, Management World, 10:100-107(in Chinese).

[24]Xie, H. \& Liu, B.(2009). Political Connection, Tunneling and Earnings Management: Empirical Evidence from Private Listed Companies in China, Proceedings of the 8th Annual Meeting of Accounting informationization.

[25]Yu, Z., Tian, G., Qi, B. \& Zhang, H.(2011). The Corporate Governance Mechanism of Media Attention: From the Perspective of Earnings Management, Management World, 9: 127-140(in Chinese). 